\title{
ПОЛЬСЬКА АРХІТЕКТУРНА СПАДЩИНА XVIII-XIX СТОЛІТТЯ НА КИЇВЩИНІ
}

\author{
Оксана Салата \\ Київський університет імені Бориса Грінченка, Київ, Україна \\ ORCID: 0000-0003-2498-1483
}

\begin{abstract}
Анотація. Стаття розкриває проблеми збереження архітектурної спадщини XVIIIXIX століть на Київщині, акцентує увагу на тому, що завдяки вивченню і збереженню маєтностей польських магнатів і шляхтичів можна прослідкувати істотні риси соціального устрою цього регіону у XVIII - XIX століттях. Як приклад, представлено історико-культурні ресурси українсько-польської спадщини Київщини, де вагоме місце займають садиби польських магнатів Браницьких, панів Червінських, Підгірських та Залєських, Тарновських. Увагу акцентовано на важливій проблемі співпраці українських фахівців у сфері збереження культурно-історичної спадщини та польськими центрами охорони і наукових досліджень польської культурної спадщини, меценатів.
\end{abstract}

Ключові слова: польська історико-архітектурна спадщина, Київщина, збереження пам’яток польської культури, магнати, шляхта, польсько-українська співпраця.

Культура є визначаючим чинником у житті будь-якого суспільства. Вона відіграє також важливу роль у житті кожної окремої людини, виступає засобом акумуляції, збереження і передачі людського досвіду. Маємо визнати, що саме культура робить людину особистістю. Рівень культури особистості визначається ії соціалізованістю - прилученням до культурної спадщини, та ступенем розвитку індивідуальних здібностей.

У будь яку епоху культура згуртовує людську спільноту, забезпечує іiі цілісність. Вона $є$ важливим чинником процесу самоідентифікації, вона визначає, хто ми є у взаєминах із собі подібними, з сусідами та з людськими спільнотами всього світу.

Скільки людських спільностей стільки й культур, ми постійно проникаємо в іншу культуру, пізнаємо безліч мов, але варто пам'ятати, що ми як громадяни однісї планети повинні розуміти один одного. Ми повинні набувати досвіду у пізнанні іншої, відмінної від нашої культури. Цей досвід збагатить нас і сприятиме підвищенню взаєморозуміння. 
Сьогодні маємо в Україні багату культурну спадщину, яка залишилася нам не лише від пращурів, але й від спільнот, з якими протягом багатьох віків ми перебували у тісних зв'язках під владою тієї чи іншої держави. Зокрема величезна культурна спадщина й архітектурна зокрема, залишилася нам від польського народу.

Більше ніж чверть століття Україна - незалежна держава. Незважаючи на це важливим питанням залишається процес усвідомлення власної культурної спадщини у контексті збереження традицій українського народу та народів, культура яких у певні періоди нашої історії інтегрувалася у наш життєвий простір. Необхідно визнати, що у цій площині наше суспільство ще має багато працювати, тому що велика кількість історичних пам'яток, зокрема пам'яток архітектури, перебувають у занедбаному стані. Незважаючи на окремі позитивні зрушення останніх років у царині збереження пам'яток, загальний стан об'єктів культурно-історичної спадщини залишається загрозливим та потребує термінових заходів для поліпшення ситуації.

Суспільство має усвідомити, що історична цінність пам'яток культури виявляється не лише у пізнавальному плані. Вони є свідками подій, або дуже віддалених, або, значних для історії і культури людства, України, даного регіону.

У пізнавальному контексті історична цінність пам'ятки культури виражається передусім у тому, що вона служить носієм інформації про минуле, тобто історичним джерелом. Ця інформація має різносторонність і проявляється в абсолютно різних сферах, що дозволяє розглядати пам'ятку як специфічне і комплексне історичне джерело. 3 точки зору істориків, первинний інтерес представляє пряме свідчення пам'яток про соціальну структуру суспільства. Так, у великій кількості пам'яток архітектури Київщини, зокрема маєтностях польських магнатів і шляхтичів, яскраво проявилися істотні риси соціального устрою цього регіону у XVIII-XIX століттяХ.

Звідси предметом нашого дослідження є проблема збереження архітектурної спадщини польської шляхти XVIII-XIX ст. на території Київщини. Серед історико-культурних ресурсів українсько-польської спадщини Київщини вагоме місце займають садиби польських магнатів Браницьких, панів Червінських у Тадіївці Сквирського району, панів Підгірських у с. Антонів, маєтності у с. Руде пана Станіслава Залєського та інші.

Польське панство Правобережжя, зокрема - Київщини стало першими латифундистами організаторами сільського господарства і промисловості. Ще в XVIII ст. тут утворились господарства Браницьких. 3 поділом Польщі з'являється нова земельна сила - російська бюрократія, що особливо зміцнилась після повстання 1830 рр., коли російський уряд провів тотальну конфіскацію польських маєтків і передав їх слухняним 
підданим на боротьбу з польським національно-державним рухом. Отже, лятифундії польських і російських панів визначали характер господарювання Правобережжя взагалі і Київщини зокрема ${ }^{1}$.

У другій половині XIX ст. Браницькі володіли значними територіями, але переважна більшість їхніх маєтностей були розташовані саме на території Київщини.

У «Статистических сведениях о Киевской губернии». за 1840 рік підкреслено, що Браницькі, тільки у Богуславському повіті (згодом Канівському) були найбільшими власниками, бо їм належало $35,2 \%$ всього закріпаченого населення в повіті, тоді як Лопухіним лише 15\%, Понятовським - $11 \%$, Тарновським - $3 \%$ та ін ${ }^{2}$.

Беручи цифри, що подає Фундуклей щодо кількості осель на Київщині в цілому і зокрема по повітах в 1845 ропі, можна припустити, що в 1840 рр. на Київщині Браницьким належало біля 10\% всіх міст і сіл.

Окремо по повітах це так розподіляється:

1) на Васильківщині $65 \%$

2) на Таращанщині 33

3) на Канівщині 26

4) на Звенигородщині 18

5) на Черкащині 4

6) на Радомищині 3

За Фундуклеєм, Браницьким належало 14\% всіх кріпаків 3

"Родове королівство Браницьких", як пізніше охрестили ці землі, стало графською власністю згідно з “жалуваною грамотою Франциску Ксаверію Браницькому на Білоцерківське староство".

У документі, зокрема, зазначалося: “Станіслав-Август Б. М. Король Польський, Великий князь Литовський, Руський, Прусський, Київський, Волинський і Чернігівський - оголошуємо настояною нашою грамотою всім і кожному, що ми, звернувши увагу на заслуги Великого Коронного Гетьмана Франциска Ксаверія Браницького, який завжди захищає благополуччя Царського трону нашого, і даруємо, а саме: містечко Біла Церква з замком, укріпленням, передмістями, і села: Шамраївку, Руду, Матюші, Безуглик, Фурси, Мазепівці і т.д., а також містечка Синяву, Пугачівку, Суховці, Криву, Насташку, Бирюки, Кам’янку, Юзефівку (згадуються інші села сучасного Рокитнянського району), з володіннями, будівлями, полями, лугами, озерами, річками, млинами, селянами, простолюдина-

1 О. Степанишина, Господарство графів Браницьких на Київщині і реформа 1861 p. в їхніх маєтках, "Студії з історії України Науково-дослідчої катедри з історії України в Київі” Т. 3: [в:] http://shron1.chtyvo.org.ua/Stepanyshyna_O/Hospodarstvo_hrafiv_ Branytskykh_na_Kyivschyni_i_reforma_1861_r_v_ikhnikh_maietkakh.pdf

2 Там само.

3 Там само. 
ми..., рогатим скотом, домашньою рухляддю. Ото ж, Великому Коронному Гетьману Ф. К. Браницькому і його нащадкам даємо, даруємо і на вічні времена уступаємо"4.

Більшість маєтностей Браницьких збереглися і були реставровані, але це переважно центральні та парадні споруди. Частина господарчих споруд, на жаль, знаходиться у досить важкому стані.

Якщо аналізувати як збереглися маєтки шляхти, то необхідно зазначити, що переважна більшість таких пам'яток в Україні знаходиться у занедбаному стані і не приваблює відвідувачів. Якщо місцева громада переймається долею споруди чи архітектурного ансамблю, то історична пам'ятка дає можливість ознайомитись 3 історичним минулим цієї місцевості та з історією того чи іншого польського шляхетського роду. Для прикладу представляємо декілька таких споруд із багатьох, що потребують уваги.

Так, потребує уваги істориків та мистецтвознавців будинок та комплекс будівель, що належали польському шляхтичу Северину Червінському у селі Тадіївка Володарського району Київської області.

На початку XVIII ст. польський шляхтич Тадеуш Крижанівський отримав у власність село Пархомівка але, щоб розширити орні землі і господарські угіддя, він переселив третину мешканців Пархомівки на окремий хутір, куди пізніше почали переселятися також люди з різних територій України та Польщі 5 . Спочатку це село називали Пархомівська Слобода, а на початку XIX ст. мешканці почали його іменувати на честь свого засновника - Тадіївкою. Родина Крижанівських володіла Тадіївкою більше як половину століття, а в 1844 р. внук Тадеуша Крижанівського продав маєток поміщику Северину Червінському, родина якого володіла цим маєтком аж до початку революції 1917 p.

Bce, що залишилося від садиби поміщика Червінського - це двоповерховий будинок челяді, збудований у другій половині XIX століття. Унікальність будівлі у тому, що їі фасадна частина прикрашена фігурною цегляною кладкою та дерев'яними карнизами, що було характерним архітектурним стилем на той час і складає великий інтерес для сучасних митців і науковців ${ }^{6}$.

Це перехідний стиль від барокової архітектури до класицизму, характерний для споруд 1-ї половини XIX століття на території східної Польщі та України. Відновлення будинку поміщиків Червінських та комплексу

\footnotetext{
4 Н. Беззубенко, Село у своїх витоків, [в:] http://savyntsi-nvo.edukit.kiev.ua/informaciya_ pro_zaklad/istoriya_sela/

5 Л. Похилевич, Сказания о населённых местностях Киевской губернии, Киев 1864, c. 236-237.

6 Р. Маленков, О. Година, Дванадиять маршрутів Київщиною. Путівник, Київ 2008, [в:] http://ukrainaincognita.com/kyivska-oblast/tadiivka
} 
архітектурних споруд, що відносяться до даного історичного періоду, дасть змогу реконструювати соціальну структуру суспільства та умови життя населення Київщини у зазначений період. Відновлення даної пам'ятки, на жаль, не стало пріоритетом ні для місцевої влади, ні для держави. Корисним, на нашу думку, був би досвід європейських країн, коли збереженням пам'яток культури займається місцева громада, оскільки така спадщина є важливою для усвідомлення своєї “малої батьківщини”.

Не менш цінною історичною та культурною пам'яткою на Київщині є також костьол родини Підгірських (1810р.), усипальниця (1806 р.) та водяний млин на річці Березанці у с. Антонові. У період панування тут Польської шляхти Антонів був невеликим містечком. На думку багатьох істориків, містечком володіла родина Вишневецьких, зокрема Єремія-Михайло Корибут-Вишневецький. Однак вже у середині XVIII ст. після смерті останнього представника Вишневецьких - Михайла-Сервасія, який не мав нащадків чоловічого роду, володіння на Київщині було розділено між декількома польськими родами‥ Отже містечко у 1765 р. отримала у володіння родина Замойських. Але після переходу Правобережної України під владу Росії містечко поступово почало занепадати і перетворилося на село.

На думку Лаврентія Похилевича, містечко було дуже заможним, мало великі зв'язки 3 навколишніми містами та селами ${ }^{8}$. Костел, збудований родиною Підгірськими, являє собою доволі оригінальну саркофальну будівлю-родинну усипальницю, за формою нагадує піраміду. На жаль, сьогодні вона знаходиться у напівзруйнованому стані і вимагає реставрації.

Про костел ні держава, ні місцева громада зовсім не піклується. За 200 років у його приміщенні жодного разу не робили капітального ремонту. Вікна зовсім без скла. Раніше на їх місці були різнокольорові вітражі з ромбічного скла. Оригінальним також є млин, зведений Підгірськими. Це монументальна двоповерхова споруда, оздоблена цегляними рельєфними елементами․․ Таких споруд на території України збереглося дуже мало, а це означає, що вони є важливою історичною та мистецькою пам'яткою.

Цінну культурно-історичну спадщину залишили нам польські магнати Збаразькі, Вишневецькі та Залєські у с. Рудому Сквирського району Київської області ${ }^{10}$.

\footnotetext{
С. Зимницька, Родові володіння Вищневецьких на території Волині, Браилавщини і Київщини в рецепиії украӥнських і польських істориків, "Гуманітарний журнал” 2009, №1-2, c. 132.

8 Л. Похилевич, Сказания о населённых местностях Киевской губернии ..., цит. праця, c. 244 .

9 Там само, c. 242-243.

10 Stownik geograficzny Królestwa Polskiego i innych krajów słowiańskich, ред. В. Chlebowski, F. Sulimierski, T. IX, Warszawa 1888, [в:] http://dir.icm.edu.pl/Slownik_geograficzny/Tom_IX/
} 
У кінці XVI - на початку XVII ст. с. Руде належало польському магнату Янушу Збаразькому. У 1608 р. він помер, а його маєтки й земельні володіння дісталися синові Юрію. Оскільки Юрій Збаразький був бездітним, то після його смерті в 1631 р. рід Збаразьких припинив своє існування. Ці володіння перейшли до магната Єремії-Михайла Корибута-Вишневецького, який у 1640 р. передав їх своєму родичу Янушу Вишневецькому. У кінці XVIII ст. с. Руде увійшло до володінь Станіслава Залєського, який стояв на чолі повітового дворянства.

На одному з найвищих пагорбів села Станіслав Залєський збудував свій палац: у двоповерховому будинку було близько 15 кімнат з бальною залою та їдальнею для челяді. Цегляні стіни мали метрову товщину, підлога була вистелена паркетом. На головній алеї, перед парадним входом було зведено фонтан. Навколо маєтку на трьох гектарах саду росли три тисячі дерев і кущів, привезених з різних куточків Європи. Від будинку розходилися вісім алей, кожна обсаджена деревами певних порід ${ }^{11}$.

У середині XIX ст. панський палац був перебудований. Мурована 3 цегли двоповерхова будівля і зараз приваблює око своєю скромною класикою, незважаючи на те, що від палацу залишився тільки фасад. На трикутному фронтоні раніше були герби власника і його дружини тепер лише барельєф із двох скульптур. Бічні частини палацу виконані у формі лоджій з відкритими колонадами. Оригінальне розпланування палацу дуже схоже на роботи італійського архітектора Андреа Палладіо (1508-1580 pр.). А це вже свідчить про те, що у цій споруді були втілені найкращі традиції європейської архітектури.

Не менш важливою пам'яткою у цьому ж селі є Свято-Троїцький храм $з$ іконою Божої Матері. Про ікону з церкви в Рудому Селі згадує у своїх Сказаннях... Леонтій Похилевич: "В окремому кіоті знаходиться вельми шанований навколишніми жителями образ Божої Матері, вклонитися якому сходиться сила-силенна людей"12. Будучи католиком Станіслав Залєський спеціально для ікони наказав збудувати православну церкву, але пан Станіслав через два роки помер, так і не завершивши будівництво. Фактично добудовували храм спадкоємці Залєського тому будівництво тривало $з$ перервами аж до 1841 року.

Нажаль у подружжя Залєських власних дітей не було, і в 1840 році власність у Рудому Селі перейшла до племінниці Залєського, Феліції Івановської, яка подарувала маєток своїй дочці Констанції. Наступним власником був син Констанції Адам Ржеуський, який передав маєток своєму

\footnotetext{
11 Архітектурні та природні пам'ятки України. Руде село, [в:] http://ukraine.kingdom. kiev.ua/region/09/rude-selo.php

12 Л. Похилевич, Сказания о населённых местностях Киевской губернии ..., цит. праця, c. 244.
} 
синові Вацлаву. Сдиною донькою Вацлава Ржеуського була Софія, вона ж - остання власниця маєтку в Рудому Селі, перебувала в шлюбі з Стефаном Подгорським ${ }^{13}$.

Пам'ятки архітектури, що знаходяться у с. Рудому, побудовані, переважно, у кінці XVIII - початку XIX ст. Незважаючи на те, що вони внесені до державного реєстру як культурне надбання, той стан, у якому вони перебувають, викликає тільки жах і сором, за нашу недбалість і байдужість.

Ще однією перлиною архітектури XVIII - початку XIX ст. є Парк Трощинських (Кагарлицький парк), що став одним із найпривабливіших місць районного центру Київщини. Це пам'ятка садово-паркового мистецтва XVIII-XIX століть. Тут люблять відпочивати місцеві мешканці, не оминають його увагою і туристи. Були часи, коли парк Трощинських змагався за першість зі знаменитою уманською Софіївкою. Тоді в його центрі височів розкішний палац із колекцією творів мистецтва і великою бібліотекою. Основні елементи паркового ансамблю, закладеного ще в XVIII ст., збереглися донині. Весь комплекс має назву “Земна куля в мініатюрі".

Наприкінці XVIII ст., польський граф Кагарлицький Ян Тарновський заклав прекрасний парк. Згодом російська цариця Катерина II подарувала садибу своєму статс-секретарю Дмитрові Трощинському. Саме він збудував тут двоповерховий палац, де було близько тридцяти залів, кімнат та флігелів і великий сонячний годинник перед входом. На жаль, до наших днів ці споруди не збереглися. Власник вніс також багато ідей для облаштування простору за зразками європейських ландшафтних парків. Парк Трощинських нагадує нашу планету в зменшеному масштабі: на ставку штучно створили острівець, який символізує материк в океані.

Дмитро Трощинський відомий також як чиновник, що займав високий ранг при імператорському дворі. Дмитро Прокопович відомий також як меценат, нащадок гетьмана Івана Мазепи і родич Миколи Гоголя. $€$ свідчення про те, що відомий письменник бував у кагарлицькому маєтку 1851 року $^{14}$.

Пізніше нащадки Дмитра Трощинського збанкрутували і продали садибу земельному банкові. Згодом іії придбав екс-командувач військ Київського військового округу Михайло Чертков. Це він запросив польського садівника Бернгарда для реконструкції парку. Тоді встановили ротонду

\footnotetext{
13 В. Миколаєнко, Руде Село, [в:] http://volodarka-rda.gov.ua/index.php?option=com content\&view $=$ article $\&$ id $=360: 2012-08-02-06-30-43 \&$ catid $=76: 2012-04-11-09-29-$ 46\&Itemid $=109$

14 О. Салій, Дмитро Трощинський і Микола Гоголь. До До 200-річчя від дня народження М. В. Гоголя, "Відлуння віків” 2009, № 1(11), [в:] http://dspace.nbuv.gov.ua/xmlui/bitstream/ handle/123456789/17603/19-Saliy.pdf?sequence=1
} 
на пагорбі, вистелили доріжки цеглою, проклали водопровід для поливання рослин, завезли з Західної Європи та Америки нові дерева й чагарники. У той же час з'явилися нові альтанки та багато скульптур із мармуру. 1918 року частину пам'яток вивезли до Німеччини, а більшість була знищена разом із палацом. Зараз за статусом парк Трощинських має загальнодержавне значення. Його площа - понад 35 гектарів. Недавно в ньому провели реконструкцію ${ }^{15}$.

У 1810 році, незадовго до своєї смерті, що настала в 1812-му році, старий єкатерининський вельможа, князь Григорій Долгорукий, продав свій маєток в Томашівці польському дворянину Івану Францевичу Хоєцькому, (1748 - 22.06.1816), нащадки якого і володіли ним протягом більш 100 років. Ян Хоєцький у 1782 р. був Брацлавським прикордонним суддею. Потім, було обрання від Київського воєводства (другого скликання), Іван Хоєцький став учасником знаменитого Чотирилітнього сейму Польщі, де він виступив активним прибічником Конституції 3-го травня і противником Тарговицької конфедерації.

Після перемоги Тарговицької конфедерації, противником якої він виступав, виїхав за кордон разом з сім'єю. Після повернення на запрошення київського єпископа Каспера Цецішовского проживав у Фастові, в орендованому у єпископа маєтку. У $1804-1816$ рр він був обраний маршалком шляхти (предводителем дворянства) Васильківського і Махновицького повітів. Висунувши ідею створення підстави школи в Київській губернії, передав для цієї мети значну суму грошей. За свою діяльність і польський патріотизм останній польський король Станіслав-Август Понятовський нагородив його орденами Білого Орла і св. Станіслава ${ }^{16}$.

Довгий час землі Томашівки залишалися незаселеними, а Томашівка становила єдиний маєток з сусіднім селом під веселою назвою Дідівщина, де Хоєцький влаштував свою головну резиденцію. Звідти він керував своїм наділом, куди так само входили Какалена, Голяки і Поліченці.

Старший син Еваріст заснував в Дідівщині цукровий завод. Приблизно в 1860-му році він одружився з Марією Страшинською. 1882 рік став фатальним для Хоєцьких - у цьому році померли і батько, і син Хоєцькі - Петро і Еваріст. $Є$ припущення, що поховані вони в костелі, який заклав в Дідівщині їх батько і дід Іван Хоєцький, а закінчила будівництво дружина Петра Хоєцького - Катерина, передбачивши у підвалі сімейну усипальню. Спадкоємцем Еваріста, який отримав і Дідівщину i Томашівку, став його син Сигізмунд. Він був останнім власником То-

\footnotetext{
15 Кагарлик, альтанка маєтку Трощинського, [в:] https://ua.igotoworld.com/ua/poi_object/71176_park-troschinskih-kagarlickiy-park.htm

16 Проект “Украйнські Архітектурні Пам'ятки. Спадщина”, [в:] https://m-a-d-m-a-x. livejournal.com/301365.html
} 
машівки i, власне, будівельником тієї садиби, яку ми зараз з вами можемо спостерігати.

Садиба вийшла легкою, цікавою і приємною. Будівля грає поверховістю, переходячи від своєї домінанти - майже триповерхової вежі до двоповерхового ризаліті, що закінчується легким критим балконом і одноповерховим корпусом, підкресленим баштовим ризалітом - входом.

Цей комплекс архітектурних споруд був збудований за проектом архітектора Валеріана Куликовського. Він створив цікаву і нестандартну будівлю у стилі модерн, яку навіть охрестили “Малим Ермітажем".

На жаль, будівлі знаходяться у поганому стані і потребують уваги 3 боку суспільства та фахівців-реставраторів. Фактично, збереглась лише церква. Мур навколо монастиря, хоч і стилізований під Середньовіччя, цілком сучасний. Дзвіниця взагалі у процесі будівництва.

Отже, розглянувши окремі садиби-маєтки польської шляхти, що були збудовані на території України протягом XVIII-XIX ст. необхідно зазначити, що такі садиби-маєтки були характерними для багатьох губернських та повітових міст і містечок, як правило складалися 3 окремого житлового будинку-особняку, службового приміщення (флігель для обслуги, господарські будівлі), саду чи парку. Вони різноманітні за своєю стилістикою, художнім задумом, монументальністю та якістю будівлі. Кожна з них демонструє художню творчість архітекторів, сумлінність будівників, які базувалися на фінансовій спроможності замовників із числа польської шляхти, магнатів.

Унаслідок історичних подій, руйнівних сил часу, знецінення об'єктів у певний період історії, а також через перебудови, переобладнання під відповідні установи, організації тощо, збереженні архітектурні пам'ятки змінили свої функції та первинний вигляд. Саме проблема збереження, передачі культурної спадщини наступним поколінням ставить перед науковцями та користувачами завдання забезпечити життєздатність історичному середовищу.

На нашу думку, збереження історичних пам'яток архітектури можна покращити за умови виконання необхідних завдань:

- забезпечити державний облік та контроль за збереженням і використанням об'єктів культурно-історичної спадщини;

- провести, з урахуванням сучасного інформаційного рівня, паспортизацію об'єктів культурно-історичної спадщини;

- сприяти залученню інвестицій у діяльність по збереженню, реставрації, реабілітації і використання пам'яток та об'єктів;

- сприяння залученню об'єктів культурної архітектурної спадщини до національних та світових туристичних маршрутів.

Отже, дуже важливо мати стратегію збереження історико-культурних пам'яток, якими і $€$ садиби-маєтки польських магнатів та шляхти- 
чів, на державному рівні. Позитивним є також досвід залучення польських організацій з охорони і наукових досліджень польської культурної спадщини та меценатів. Співпраця польських й українських вчених вже має позитивний досвід відновлення замків у Львівській та Волинській областях.

\section{БІБЛІОГРАФІЯ}

Arhitekturnì ta prirodnì pam âtki Ukraïni. Rude selo. V: http://ukraine.kingdom.kiev.ua/ region/09/rude-selo.php [Архітектурні та природні пам'ятки України. Руде село. B: http://ukraine.kingdom.kiev.ua/region/09/rude-selo.php].

Bezzubenko Nadiâ. Selo u svoïh vitokì. V: http://savyntsi-nvo.edukit.kiev.ua/ informaciya_pro_zaklad/istoriya_sela/ [Беззубенко Надія. Село у свойх витоків. В: http://savyntsi-nvo.edukit.kiev.ua/informaciya_pro_zaklad/istoriya_sela/].

Kagarlik, al'tanka maêtku Troŝins'kogo. V: https://ua.igotoworld.com/ua/poi_object/71176_park-troschinskih-kagarlickiy-park.htm [Кагарлик, альтанка маєтку Трощинського. В: https://ua.igotoworld.com/ua/poi_object/71176_park-troschinskih-kagarlickiy-park.htm].

Malenkov Roman, Godina Oleg. 2008. Dvanadcât' maršrutìv Kï̈vsinoû. Putivnik. Kï̈v: Granì-T. V: http://ukrainaincognita.com/kyivska-oblast/tadiivka [Маленков Роман, Година Олег. 2008. Дванадиять маршрутів Київщиною. Путівник. Київ: Грані-T. B: http://ukrainaincognita.com/kyivska-oblast/tadiivka].

Mikolaênko V. 2012. Rude Selo. V: http://volodarka-rda.gov.ua/index.php?option=com content\&view $=$ article \&id $=360: 2012-08-02-06-30-43 \&$ catid $=76: 2012-04-11-09-$ 29-46\&Itemid=109 [Миколаєнко В. 2012. Руде Село. B: http://volodarka-rda. gov.ua/index.php?option $=$ com_content $\&$ view $=$ article $\&$ id $=360: 2012-08-02-06-30$ 43\&catid=76:2012-04-11-09-29-46\&Itemid=109].

Pohilevič Lavrentìj. 1864. Skazaniâ o naselënnyh mestnostâh Kievskoj gubernii. Kiev: Kievo-Pečerskaâ lavra [Похилевич Лаврентій. 1864. Сказания о населённыхх местностях Киевской губернии. Киев: Киево-Печерская лавра].

Proekt "Ukraïns'ki Arhitekturnì Pam 'âtki. Spadŝina”. V: https://m-a-d-m-a-x.livejournal. com/301365.html [Проект “Українські Архітектурні Пам'ятки. Спадщчин”. В: https://m-a-d-m-a-x.livejournal.com/301365.html].

Salìj Oleksandr. 2009. Dmitro Troŝins'kij ì Mikola Gogol'. Do 200-rǐččâ vìd dnâ narodžennâ M. V. Gogolâ. "Vìdlunnâ vìkìv" № 1(11): 72-76. V: http://dspace.nbuv.gov.ua/xmlui/ bitstream/handle/123456789/17603/19-Saliy.pdf?sequence=1 [Салій Олександр. 2009. Дмитро Трощинський і Микола Гоголь. До 200-річчя від дня народження М. В. Гоголя. "Відлуння віків” № 1(11): 72-76. B: http://dspace.nbuv.gov.ua/xmlui/ bitstream/handle/123456789/17603/19-Saliy.pdf?sequence=1].

Stownik geograficzny Królestwa Polskiego i innych krajów słowiańskich. 1888. Red. Chlebowski B., Sulimierski F. T. IX. Warszawa: Nakładem Władysława Walewskiego. V: http://dir.icm.edu.pl/Slownik_geograficzny/Tom_IX/

Stepanišina Oksana. 1930. Gospodarstvo grafiv Branic'kih na Kï̈vsini i reforma 1861 r. $v$ ïhnih maêtkah. "Studiï z ìstoriï Ukraïni Naukovo-doslìdčoï katedri z ìstoriï Ukraïni v Kiïvi” T. 3: 117-232. V: [Степанишина Оксана. 1930. Господарство графів Браницьких на Київщині і реформа 1861 р. в їхніх маєтках. "Студії з історії України Науково-дослідчої катедри з історії України в Київі” Т. 3: 117-232. В: http:// 
shron1.chtyvo.org.ua/Stepanyshyna_O/Hospodarstvo_hrafiv_Branytskykh_na_ Kyivschyni_i_reforma_1861_r_v_ikhnikh_maietkakh.pdf].

Zimnic'ka Svitlana. 2009. Rodovì volodìnnâ Višnevec'kih na Teritorï̀volinì, Braclavsinini i Kï̈vsini v recepciï ukraïns'kih ì pol's'kih istorikiv. "Gumanìtarnij žurnal” № 1-2: 127133 [Зимницька Світлана. 2009. Родові володіння Вишневецьких на території Волині, Бращлавщини і Київщини в рецепції українських і польських істориків. “Гуманітарний журнал” № 1-2: 127-133].

\title{
POLISH ARCHITECTURAL HERITAGE OF THE XVIII-XIX CENTURIES IN KYIV REGION
}

\begin{abstract}
Summary. In the article is revealed the problem of preserving the architectural heritage of the XVIII-XIX centuries in Kyiv region, emphasized the fact that due to the investigation and preservation of Polish magnates and noblemen estates, it is became possible to trace peculiarities of the social structure of this region in the XVIII-XIX centuries. As an example, the historical and cultural sources of the Ukrainian-Polish heritage of Kyiv region are presented, and pointed out the importance of the mansions of the Polish magnates Branicki, representatives of Chervinsky, Podgorsky and Zaleski, and Tarnovsky noble families. It is underlined the issue of cooperation of Ukrainian specialists in the field of preservation of cultural-historical heritage and Polish centers of protection and scientific research of the Polish cultural heritage, patrons.
\end{abstract}

Key words: Polish historical and architectural heritage, Kyiv region, preservation of the monuments of Polish culture, magnates, gentry, Polish-Ukrainian cooperation.

\section{POLSKA SPUŚCIZNA ARCHITEKTONICZNA XVIII-XIX WIEKU W OBWODZIE KIJOWSKIM}

Streszczenie. Niniejszy artykuł poświęcono problematyce zachowania polskiej spuścizny architektonicznej XVIII-XIX w. na Kijowszczyźnie. Autorka podkreśla, że dzięki należytemu zbadaniu oraz zachowaniu dóbr polskiej szlachty i polskich magnatów można będzie prześledzić i uwidocznić istotne cechy struktury społecznej tego regionu na przestrzeni XVIII-XIX w. Za przykład posłużyły Autorce elementy ukraińsko-polskiego dziedzictwa historyczno-kulturowego na Kijowszczyźnie, gdzie znaczące miejsce zajmują dwory polskich magnatów i szlachty należących do takich rodów, jak Braniccy, Czerwińscy, Podgórscy, Zalescy czy Tarnowscy. W trakcie przeprowadzania analiz Autorka przyjrzała się także niezwykle istotnym zagadnieniom w zakresie współpracy ukraińskich ekspertów zajmujących się ochroną dziedzictwa kulturowego i historycznego oraz polskich centrów badań i ochrony polskiego dziedzictwa kulturowego.

Słowa kluczowe: polska spuścizna historyczno-architektoniczna, zachowanie zabytków kultury polskiej, magnaci, szlachta, współpraca polsko-ukraińska. 